https://nv.nltu.edu.ua

https://doi.org/10.36930/40290922

Article received $20.11 .2019 \mathrm{p}$.

Article accepted 26.12.2019 p.

$@ \bowtie$ Correspondence author

M. P. Bosak

UDK 628.[112.24+144.22]:532.542.1

\title{
bosmykpan@ukr.net
}

\author{
М. П. Босак ${ }^{1}$, М. С. Одуха' ${ }^{2}$, О. Г. Гвоздецький ${ }^{1}$, В. Є. Фасуляк ${ }^{1}$ \\ ${ }^{1}$ Національний університет "Львівська політехніка", м. Львів, Украӥна \\ 2 Львівське міське комунальне підприємство "Львівводоканал", м. Львів, Україна
}

\section{ДОСЛІДЖЕННЯ ЕКСПЛУАТАЦІЙНОГО РЕЖИМУ СВЕРДЛОВИН ВОДОЗАБОРУ ТА ВОДОГОНУ}

\begin{abstract}
Наведено результати гідравлічних досліджень експлуатаційних режимів роботи водогону на ділянці від водозабору до підвищувальної насосної станції. Визначено та обгрунтовано режим експлуатації водогону на підставі гідравлічних досліджень і експлуатаційних показників роботи свердловин. Через наявність рельєфного водорозділу траса водогону за довжиною знижується від водозабору на 52 м до підвищувальної насосної станції. З'ясовано експлуатаційний режим роботи насосів свердловин включно з фактичним їх напором. Встановлено, що експлуатаційний напір насосів свердловин, який становить 30 м, є надлишковим для цих умов. Отож, доцільно замінити та модернізувати насоси свердловин на насоси 3 нижчим напором, та вищим коефіцієнтом корисної дії. З'ясовано наявність безнапірної і напірної течії води у водогоні залежно від величини подачі води. Встановлено, що безнапірна течія характерна для витрат води, близьких до середньогодинних у діапазоні 3000-4000 м³/год. За більших витрат води у водогоні наявний напірний режим течії. Визначено необхідний напір насосів свердловин з урахуванням режиму роботи водогону. Величина подачі води у водогоні насосами свердловин водозабору і подача води підвищувальною насосною станцією переважно не збігаються, тому тиск води у водогоні змінний. Обгрунтовано доцільність експлуатації свердловин у режимі з перервою роботи насосів свердловин на 2 год за добу. Відтак водогін, у межах водозабірних свердловин, спорожниться і режим роботи свердловинних насосів буде в області малих напорів та більшої подачі води. Внаслідок цього зменшиться витрата електроенергії. Виконано порівняння економічності експлуатації насоса ЕЦВ 12-255-30 та насоса SP 270-1L-G. Запропонований режим роботи свердловин дає можливість зменшення експлуатаційних витрат електроенергії.
\end{abstract}

Ключові слова: свердловини; водогін з підвищувальною насосною станцією; режим експлуатації; напірний та безнапірний режими роботи.

Вступ. Водогони та водозабірні свердловини є важливими компонентами водопроводу для великих міст. При цьому витрата електроенергії насосів на транспортування води є значною, особливо якщо водогін значної довжини (у випадку віддаленого водозабору) та наявності підвищувальної насосної станції (ПНС). Потужність та витрата електроенергії насосами свердловин та ПНС залежить від величин подачі та напору води. Якщо свердловинні насоси експлуатуються 3 параметрами подачі чи напору води, які не відповідають гідравлічному режиму водогону, тоді їхні робочі точки зазвичай знаходяться в області нижчих коефіцієнтів корисної дії з непродуктивною витратою електроенергії. Свердловинні насоси на водозаборі "Стрий" встановлювали 3 розрахунку на перспективне збільшення водоспоживання. Але оскільки такого не сталося, то використання насосів 3 таким напором економічно невигідне. Окрім цього, коефіцієнт корисної дії цих насосів не перевищує $60 \%$.

Вважаємо, що для зменшення енергоспоживання свердловинами, що подають воду безпосередньо у водогін, важливим є вибір насосного обладнання, яке відповідає напору та гідравлічному режиму течії води у водогоні. Необхідний раціональний режим експлуатації свердловинних насосів та водогону можна визначити та обгрунтувати в процесі спеціальних гідравлічних досліджень. Зменшення експлуатаційних витрат електроенергії дає можливість здешевити вартість води для населення.

Актуальність роботи полягає у тому, щоб дослідити гідравлічний режим роботи водогону з істотним ухилом траси його до ПНС, а результати дослідження використати для зменшення витрат енергії свердловинними насосами.

Аналіз літературних джерел. Щодо експлуатації водопроводу науково-технічні роботи найчастіше стосуються забезпечення необхідного технічного стану, зменшення витрат електроенергії для експлуатації насосів, якості води тощо. Для оптимізації експлуатаційних вит-

\section{Інформація про авторів:}

Босак Микола Панасович, канд. техн. наук, доцент, кафедра гідравліки і сантехніки. Email: bosmykpan@ukr.net; https://orcid.org/0000-0003-0306-9583

Одуха Микола Сергійович, головний технолог. Email: gteh_lvk@ukr.net; https://orcid.org/0000-0002-2654-6154

Гвоздецький Олександ Григорович, канд. техн. наук, доцент, кафедра гідравліки і сантехніки. Email: oleksandr507@gmail.com; https://orcid.org/0000-0001-5590-4689

Фасуляк Вадим Євгенійович, магістрант, кафедра гідравліки і сантехніки. Email: vadim.fasulyak@gmail.com; https://orcid.org/0000-0002-8734-0387

цитування за ДСТУ: Босак М. П., Одуха М. С., Гвоздецький О. Г., Фасуляк В. Є. Дослідження експлуатаційного режиму свердловин водозабору та водогону. Науковий вісник НлтУ України. 2019, т. 29, № 9. С. 126-131.

Citation APA: Bosak, M. P., Odukha, M. S., Hvozdetskiy, O. H., \& Fasuliak, V. Ye. (2019). Research of the operation mode of performance of water supply and water intake wells. Scientific Bulletin of UNFU, 29(9), 126-131. https://doi.org/10.36930/40290922

126 Науковий вісник НЛтУ України, 2019, т. 29, № $9 \quad$ Scientific Bulletin of UNFU, 2019, vol. 29, no 9 
рат у системах водопостачання розробляють та використовують математичні моделі та комп'ютерні програми, впроваджують насоси зі змінною частотою обертання.

Досить ефективним для енергоспоживання в системі водопостачання (Nor, 2017) є регулювання частоти обертання насоса в період надлишкових напорів у водопроводі. Обчислено математичні моделі оптимального графіка капітального ремонту насосів насосної станції внаслідок його спрацювання за постійного використання та зменшення подачі води (Anis, 2018). Розроблено методологію дослідження насосів із змінною швидкістю робочого колеса для мінімізації експлуатаційних витрат (Fang et al., 2011). Проте ці дослідження не охоплюють різних режимів течії у водогонах.

Метод оцінювання ефективності диверсифікації водозабору та об'ємів мережевих резервуарів для води дає можливість порівняти надійність різних систем водопостачання (Rak \& Boryczko, 2017). Оптимальні схеми розподілу води в мережі водопроводу дають змогу знизити на 6-8 \% прямі витрати на електроенергію та технічне обслуговування, а також збільшити гідравлічну надійність системи, максимізуючи наявний об'єм води в резервуарах для зберігання (Sousa, Covas \& Ramos, 2007). Проте ці дослідження належать до водорозподільної мережі.

Надійність насосної станції водопостачання можна оцінити на підставі показника готовності найефективніших матеріалів, конструкцій, технічних і технологічних рішень, структурних, стратегічних (Wiśniewska et al., 2017). Дослідники (Filipek \& Kulig, 2018) вважають, що вагомим для правильної та тривалої роботи системи водопостачання $є$ належна підготовка ії до експлуатації. Ці роботи спрямовані на забезпечення надійності роботи системи водопостачання.

Методику розрахунку напірних водозбірних трубопроводів, розроблену на підставі диференціального рівняння руху рідини зі змінною витратою (Chernyuk \& Orel, 2009), можна застосувати для ділянки водогону, де під'єднуються свердловини.

Відповідність роботи насосів свердловини водозабору гідравлічному режиму водогону, енергозберігаюче обладнання з повною автоматизацією процесів дає економічний ефект (Lukyn, Usachev \& Hordeichyk, 2018). Ця робота важлива, проте не поширюється на всі водогони та випадки їх експлуатації.

На прикладі довгого водоводу та значного перепаду його висот наведено аналіз режимів роботи та запропоновано послідовність його введення в експлуатацію (Prodous \& Terekhov 2018). Ця робота стосується запобігання гідроудару та випуску повітря з водогонів.

Запропоновано новий метод оптимізації експлуатаційних витрат для систем водопостачання в умовах зменшення споживання води із впровадженням програмного пакету Trace - BK (Chupin \& Pham, 2019). Ця методика дає змогу виявити малоефективні ділянки кільцевої мережі, перерозподілити потоки води в мережі та керувати роботою насосних станцій в режимі найвищої ефективності. Запропоновано оптимальну гідравлічну модель водорозподільної мережі (ODWatN) 3 нелінійних рівнянь для техніко-економічного обгрунтування та попереднього планування проектів (Kadar \& Bariudin, 2004). Концепцію інтегрованої інформаційної системи комплексного управління водними мережами розроблено в Інституті системних досліджень (IBS
PAN) у Варшаві. За допомогою цієї системи можна вирішити кілька завдань з управління водопровідними мережами, планування водопровідної мережі, контроль насосів у водопровідних насосних станціях тощо (Studzinski \& Kurowski, 2014; Kurowski, 2015). Ці роботи важливі, але вони не охоплюють умов водогону, які є в нашому випадку.

У роботі (Vieira \& Ramos, 2009) подано інформацію про модель оптимізації MATLAB та про гідравлічний тренажер (EPANET) для перевірки роботи системи водопостачання. Використання зайвого напору в системі пропонують гідротурбіною, що, на наш погляд, має практичне значення.

В опрацьованих літературних джерелах немає публікацій про взаємовплив та використання гідравлічного режиму водогону для оптимізації роботи насосів водозабірних свердловин. Це дає підставу вважати, що обрана тема роботи є актуальною.

Об'єктом дослідження є свердловини водозабору "Стрий" та ділянка водогону до підвищувальної насосної станції.

Предмет дослідження - методи і засоби визначення гідравлічного режиму роботи водогону, його необхідних параметрів і режиму експлуатації свердловинних насосів. Метод дослідження - теоретичний аналіз на базі експлуатаційних показників роботи свердловин та характеристик водогону.

Мета дослідження - визначити та обгрунтувати режим експлуатації свердловинних насосів водозабору для зменшення експлуатаційних витрат електроенергії на підставі дослідження роботи водогону.

Для досягнення зазначеної мети потрібно виконати такі основні завдання дослідження: дослідити гідравлічний режим (напірний та безнапірний) водогону; визначити взаємовплив гідравлічних характеристик і рекомендувати режим експлуатації свердловинних насосів.

Науковою новизною роботи є те, що розроблений метод дає змогу обгрунтувати доцільність експлуатації свердловин у режимі з перервою роботи насосів свердловин на 2 год за добу, внаслідок чого водогін, у межах водозабірних свердловин, спорожниться і режим роботи свердловинних насосів буде в області малих напорів і більшої подачі води.

Практична значущість результатів дослідження полягає в тому, що визначений взаємовплив гідравлічних характеристик водогону та свердловинних насосів водозабору "Стрий" можна врахувати для експлуатації цього та аналогічних водогонів, що дає змогу зменшити експлуатаційні витрати електроенергії.

Викладення основного матеріалу. У складі водозабору "Стрий" є 34 свердловин. Характерною особливістю водогону від водозабору "Стрий" є його геодезичне зниження на 50 м на відстані від водозабору до підвищувальної насосної станції.

Фактична подача води від цього водозабору за останні роки в середньому становить $87000 \mathrm{~m}^{3} /$ добу, проектна продуктивність водозабору істотно вища. Свердловини в зоні водозабору розташовані від водогону на відстані до 100 м, більшість їх сполучені з ним безпосередньо (рис. 1,6) і частина - групами (див. рис. 1,б). Довжина і діаметр водогону: 46,2 км від початку водозабору до ПНС діаметром 1200 мм; 2800 м у межах водозабору діаметром 1000 мм на початку та 1800 м діаметром 1200 мм. Об'єм водогону становить близько 50 тис. $\mathrm{M}^{3}$. 
Витрату води у водогоні за безнапірної течії води у водогоні визначили за формулою (Konstantinov \& Hizha, 2006)

$$
Q=A K_{n} \sqrt{i},
$$

де: $A$ - відносна витратна характеристика, що залежить від ступеня наповнення труби; $K_{n}-$ витратна характеристика труби за повного іiї наповнення, що залежить від діаметра або матеріалу труби; $i$ - похил водогону.

$$
K_{n}=\omega_{n} W_{n},
$$

де $W_{n}$ - швидкісна характеристика водогону в разі заповнення його на весь поперечний переріз.

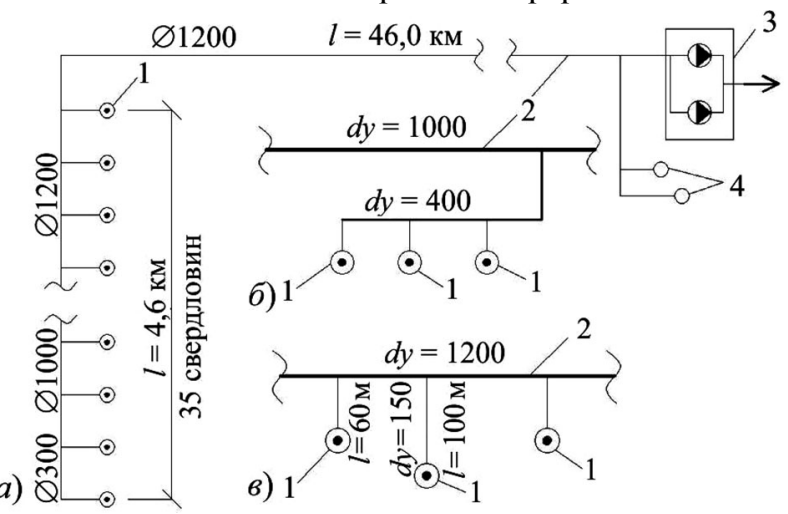

Рис. 1. План-схема водогону та свердловин водозабору: a) план-схема; б) схема групового під'єднання свердловин на початку водогону; 6 ) схема прямого під'єднання одиночних свердловин; 1 - свердловина; 2 - водогін; 3 - насосна підвищувальна станція (НПС); 4 - резервуар води

Середню швидкість води у водогоні визначили за формулою

$$
V=B W_{n} \sqrt{i},
$$

де $B$ - відносна швидкісна характеристика, яка залежить від ступеня наповнення води у водогоні.

Для гідравлічного розрахунку напірного водогону труб за $V \geq 1,2$ м/с застосували формулу (Shevelev \& Shevelev, 2007)

$$
i=0,00107 \frac{V^{2}}{d^{1,3}},
$$

де: $i$ - гідравлічний похил; $d$ - внутрішній діаметр трубопроводу, м; $V$ - середня швидкість руху рідини, м/с.

Дослідження гідравлічного режиму роботи водогону. Для аналізу гідравлічного режиму свердловин водозабору та водогону прийняли витрати водогону $Q_{\text {mid }}=3300 \mathrm{~m}^{3} /$ год, а $Q_{\max }=5000 \mathrm{~m}^{3} /$ год, за яких можливий безнапірний або напірний режими течії води. Витратну характеристику $K_{n}$, а також $A, B, W_{n}$, для різного ступеня наповнення водогону використали 3 (Konstantinov \& Hizha, 2006). Коефіцієнт шорсткості $n=0,013$. Результати гідравлічного розрахунку водогону внаслідок витрат води, близьких до середньогодинних, звели в табл. 1. У разі якщо на окремих ділянках по трасі водогону його похил буде істотно змінюватись, то безнапірна течія буде з ділянками підпору або спаду поверхні води. Отже, самоплинної безнапірної течії у водогоні не буде, якщо водогін прокладений по горбистій місцевості.

Втрати напору $\Delta h$ води за довжиною $L$ водогону визначили за формулою

$$
\Delta h=i \cdot L .
$$

У разі витрати $Q_{\max }=5000 \mathrm{~m}^{3} /$ год $=1,39 \mathrm{~m}^{3} / \mathrm{c}$, і відповідно швидкості $V=1,23$ м/с, гідравлічний похил, вирахуваний за формулою (4), становить

$$
i=0,00107 \frac{1,23^{2}}{1,2^{1,3}}=0,00126 .
$$

Отже, втрати напору за довжиною 46200 м водогону становлять 58,2 м. У місці під'єднання свердловини № 2 п'єзометричний напір становить 10 м (з урахуванням заглиблення водогону 2,0 м). Далі до свердловини № 22 середнє значення гідравлічного похилу $\approx 0,001$,

\begin{tabular}{|c|c|c|c|c|c|c|c|c|}
\hline Ділянка & Діаметр, мм & $Q \mathrm{~m}^{3} /$ год & $i$ & $W_{n} \mathrm{M} / \mathrm{c}$ & Глибина води, м & $A$ & $V \mathrm{M} / \mathrm{c}$ & Режим течії \\
\hline \multirow{2}{*}{$\begin{array}{c}0-1 \\
\text { св 34-30 }\end{array}$} & \multirow{2}{*}{300} & 250 & \multirow{2}{*}{0,004} & & 0,30 & & 0,98 & \multirow{2}{*}{$\begin{array}{c}\text { напірний } \\
(i=0,00455) \\
(i=0,0075)\end{array}$} \\
\hline & & 480 & & & 0,30 & & 1,89 & \\
\hline \multirow{2}{*}{$\begin{array}{c}1-2 \\
\text { св } 30-20\end{array}$} & \multirow{2}{*}{1000} & 1653 & \multirow{2}{*}{0,004} & 31,25 & 0,40 & 0,297 & 1,57 & \multirow{2}{*}{ безнапірний } \\
\hline & & 2448 & & 31,25 & 0,50 & 0,44 & 1,73 & \\
\hline \multirow{3}{*}{$\begin{array}{c}2-3 \\
\text { св } 20-10\end{array}$} & \multirow{3}{*}{1200} & 1625 & \multirow{3}{*}{0,004} & 35,20 & 0,46 & 0,18 & 1,58 & \multirow{3}{*}{ безнапірний } \\
\hline & & 2681 & & 35,20 & 0,48 & 0,297 & 1,77 & \\
\hline & & 3972 & & 35,20 & 0,60 & 0,44 & 1,95 & \\
\hline \multirow{2}{*}{$\begin{array}{c}3-4 \\
\text { св } 10-2\end{array}$} & \multirow{2}{*}{1200} & 2681 & \multirow{2}{*}{0,004} & 35,20 & 0,48 & 0,297 & 1,77 & \multirow{2}{*}{ безнапірний } \\
\hline & & 3972 & & 35,20 & 0,60 & 0,44 & 1,95 & \\
\hline \multirow{2}{*}{ 4-НПС } & \multirow{2}{*}{1200} & 3300 & \multirow{2}{*}{0,001} & 35,20 & 0,84 & 0,74 & 1,10 & \multirow{2}{*}{ напівнапірний } \\
\hline & & 3972 & & 35,20 & 0,96 & 0,87 & 1,13 & \\
\hline
\end{tabular}
$\Delta h=2,8$ м, а п'єзометричний напір $\approx 1,0$ м. На ділянках між свердловинами 25-30 гідравлічний режим буде напівнапірний. Відображення режимів течії за довжиною водогону для різних витрат води навели на рис. 2.

Табл. 1. Гідравлічний режим роботи водогону за витрат вод, близьких до середньо-годинних (до 4000 м $3 /$ год)

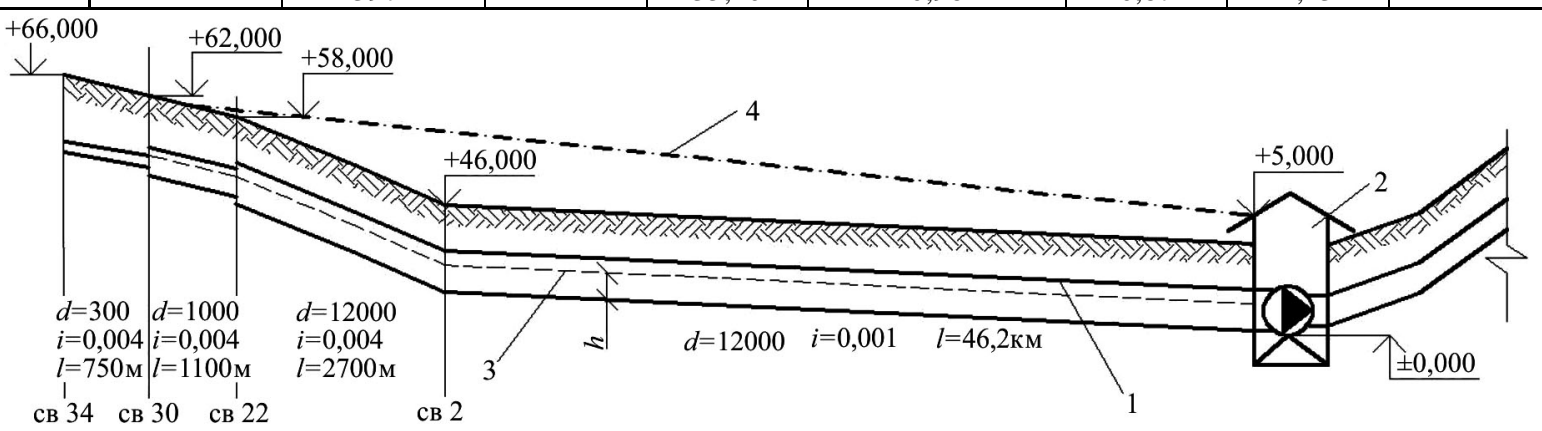

Рис. 2. Гідравлічний режим роботи водогону на ділянці від водозабору до ПНС: 1) водогін; 2) ПНС; 3) поверхня води безнапірної течії за малих і середніх витрат води до $4000 \mathrm{~m}^{3} /$ год; 4) лінія п'єзометричного напору (напірний режим за $Q_{\max }=5000 \mathrm{~m}^{3} /$ год) 


\section{Дослідження режимів експлуатації свердловин $\boldsymbol{i}$} водогону. Вода, яку забирають свердловини, - грунтова та інфільтраційна 3 річки. Грунти водозабору - гравійно-галькові з високим коефіцієнтом фільтрації. Глибина до динамічного рівня свердловини 5,2-6,2 м (рис. 3). Втрати напору насосів від свердловин, сполучених напряму з водогоном, становить до 1,5 м, а в тих, що під'єднані групами окремим трубопроводом - 2-3 м. Отже, розрахунковий напір води насосів свердловин для подачі води у водогін становить близько 10 м. Напір свердловинних насосів на початковій ділянці водогону між свердловинами № 1-15 буде вищий внаслідок напірного режиму течії у водогоні. У разі істотного небалансу подач води ПНС та насосами свердловин із підвищенням тиску у водогоні зміниться напір свердловинних насосів.

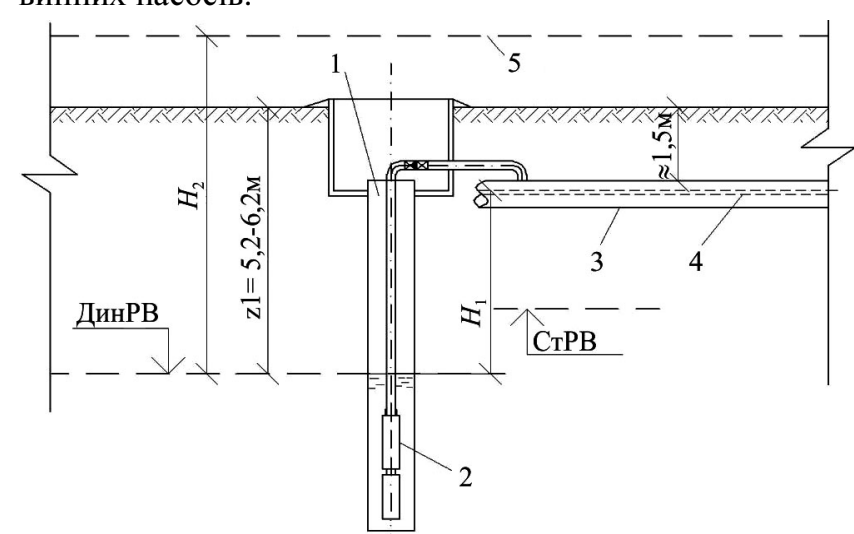

Рис. 3. Схема до визначення необхідного напору насосів водозабірних свердловин: 1) водогін; 2) свердловини; 3) водогін; 4) рівень води у водогоні за безнапірної течії; 5) п'єзометричний напір за напірної течії у водогоні; ДинРВ - динамічний рівень води, глибина до якого z; СтРВ - позначка статичного рівня води; $H_{1}$ - розрахунковий напір насоса свердловини за безнапірної течії; $H_{2}$ - теж за напірної течії у водогоні

Згідно 3 аналізом експлуатації свердловин, впродовж року вони перебувають у роботі: 20-24 год на добу працюють 10 свердловин (30\% від загальної кількості), 10-13 год - 5 свердловин (16\%); 18 год - 4 свердловини (10\%) і 13 свердловин (38\%) знаходяться в резерві. На підставі викладених даних отримуємо трьохступінчастий режим роботи свердловин (рис. 4). Для великої місткості довгого водогону базовою є рівномірна подача води свердловинами, які постійно працюють. Період і кількість роботи решту свердловин жорстко не прив'язана до пікового періоду водоспоживання.

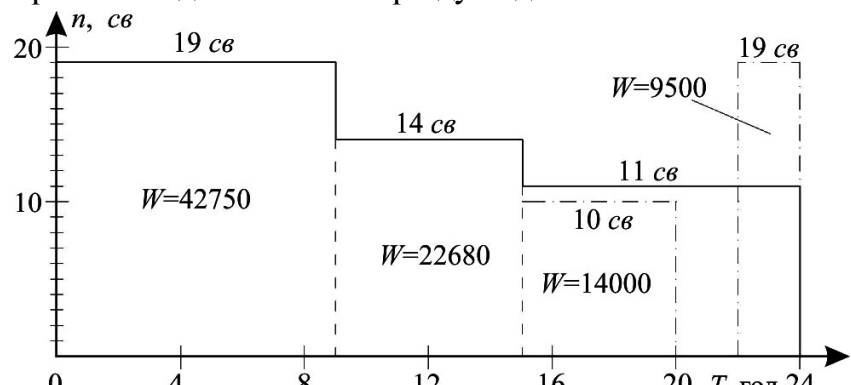

Рис. 4. Графік роботи свердловин: $n$ - кількість свердловин; $W=$ 22680 об'єм подачі води свердловинами, ${ }^{3}$

Згідно з експлуатаційними даними, за місячної подачі води $Q=2694$ тис. м ${ }^{3}$ витрата електроенергії становить $\mathrm{N}=423600$ кВт.год.

Визначимо 3 яким фактичним напором працювали насоси ЕЦВ 12-255/30, отримаємо

$$
H=\frac{N \eta 3600}{Q g K}=\frac{4236000 \cdot 0,57 \cdot 3600}{2694000 \cdot 9,81 \cdot 1,05}=31,6 \mathrm{M},
$$

де: $\eta$ - к.к.д. насосного агрегату $57,1 \% ; K=1,05$ - коефіцієнт, який враховує витрату електроенергії на допоміжні потреби.

Величина визначеного напору (31,6 м) свідчить, що насоси працювали 3 надлишковим напором, який перевищує необхідний. Причинами такого неекономного експлуатаційного режиму можуть бути:

- перевищення подачі насосів свердловин водозабору над подачею ПНС з відповідним підвищенням напору води у водогоні;

• часткове прикриття засувок на напірній лінії свердловинних насосів.

Останнє можна обгрунтувати, якщо подача насосів (за низьких напорів перевищує дебіт свердловин. Відомо, що в конкретному перерізі водопроводу складовими у формулі витрати води є площа поперечного перерізу та швидкість течії води. Проте для довгих водогонів важливим і визначальним $є$ необхідна швидкість протікання $V_{1}$ розрахункового об'єму води за добу від водозабору до водоспоживача, а в нашому випадку - до ПНС. Необхідну швидкість $V_{1}$ протікання об'єму води по водогону до ПНС можна визначити за формулою

$$
V_{l}=\frac{W}{\omega T}, \text { м/год, }
$$

де: $W$ - добове водоспоживання, ${ }^{3} /$ добу; $T$ - період протікання води по водогону, 24 год; $\omega$ - площа живого перерізу потоку води у водогоні, м $^{2}$.

Згідно з формулою (6), для добового (фактичного) водоспоживання 87 тис. $\mathrm{m}^{3} /$ добу, $Q_{m i d}=3625 \mathrm{~m}^{3} /$ год, $V_{1}=$ 3228 м/год або $0,90 \mathrm{~m} / \mathrm{c}$. Таку витрату водогін пропускає за безнапірної течії з наповненням 0,90 м. Гідравлічна швидкість $V$ води для цієї витрати становить $1,85 \mathrm{~m} / \mathrm{c}$ при $i=0,004$ та $1,10 \mathrm{~m} / \mathrm{c}$ при $i=0,001$. Подача води по водогону буде стабільною за умови $V_{l} \geq V$. Ідеальним режимом була б рівність швидкостей $V_{1}=V$. Проте внаслідок різних характеристик $Q-H$ свердловинних насосів та ПНС такий режим малоймовірний. Тому внаслідок перевищення подачі води по водогону тиск у ньому буде зростати зі зниженням подачі води свердловинних насосів до параметру, коли настане рівність подачі насосів свердловинних і ПНС. Робота насосів в області високих напорів із низьким коефіцієнтом корисної дії. Важливо, щоб робочі характеристики насосів свердловин якомога найбільше відповідали необхідним параметрам напору і подачі води.

Особливістю цього водогону є наявність істотного геометричного напору внаслідок зниження місцевості по його трасі. Тому цей фактор варто використовувати для подачі води самопливом в окремі години доби. Насоси свердловини у визначений період вимикають, а в наступні години вмикають $з$ форсованою подачею води. Проте остання не повинна перевищувати дебіт свердловини. У табл. 2, 3 навели результати техніко-економічного розрахунку режимів експлуатації свердловин.

У табл. 2, 3: $N$, кВт - потужність одного насоса; $\Sigma N$ $=n N T-$ загальна потужність насосів свердловин за години роботу протягом доби, де $T=24$ год - тривалість роботи насоса свердловини. Величини к.к.д ( $)$ насосів SP 270-L1-G та ЕЦВ 12-255/30 - прийняті з каталогів (Livnynasos, 2019; Grundfos, 2019). 
Табл. 2. Технічні характеристики та витрати електроенергії насосів свердловин під час роботи їх 3 перервою

\begin{tabular}{|c|c|c|c|c|c|c|c|}
\hline $\begin{array}{c}\text { Тривалість роботи } \\
\text { (час роботи) } \\
\text { на добу }\end{array}$ & \multicolumn{9}{|c|}{ Насоси SP 270-L1-G } \\
\cline { 2 - 8 } & $Q, \mathrm{~m}^{3} /$ год & $H$, м.вод. ст. & $\eta, \%$ & $N$, кВт & К-сть насосів & $W, \mathrm{~m}^{3} /$ добу & $\Sigma$ N, кВт год \\
\hline $11(22-09)$ & $250 / 270$ & $35 / 16$ & $78 / 79$ & $30,4 / 14,9$ & $19 / 17$ & $52250 / 50490$ & $6353,6 / 2786$ \\
\hline $6(09-15)$ & $270 / 300$ & $30 / 12$ & $77 / 79$ & $28,7 / 12,5$ & $14 / 13$ & $22680 / 23400$ & $2410,8 / 975$ \\
\hline $5(15-20)$ & $280 / 320$ & $28 / 10$ & $74 / 75$ & $28,9 / 11$ & 10 & $14000 / 16000$ & $1445 / 550$ \\
\hline $0(20-22)$ & 0 & - & & 0 & 0 & 0 & 0 \\
\hline Всього за добу 22 & & & & & & $88930 / 89890$ & $10209,4 / 4311$ \\
\hline
\end{tabular}

Табл. 3. Технічні характеристики та витрати електроенергії насосів свердловин під час роботи у звичайному режимі

\begin{tabular}{|c|c|c|c|c|c|c|c|}
\hline $\begin{array}{c}\text { Тривалість роботи } \\
\text { (час роботи) } \\
\text { на добу }\end{array}$ & \multicolumn{9}{|c|}{ Насоси SP 270-L1 - G } \\
\cline { 2 - 8 } & $Q, \mathrm{~m}^{3} /$ год & $H$, м.вод. ст. & $\eta, \%$ & $N$, кВт & К-сть насосів & $W, \mathrm{~m}^{3} /$ добу & $\Sigma$ N, кВт год \\
\hline $9(00-09)$ & $230 / 245$ & $36 / 20$ & $79 / 79$ & $28,6 / 16,9$ & 19 & $39330 / 41895$ & $4890,6 / 2860$ \\
\hline $6(9-15)$ & $250 / 250$ & $35 / 18$ & $78 / 79$ & $30,4 / 15,5$ & 14 & $21000 / 21000$ & $2553,6 / 1302$ \\
\hline $9(15-24)$ & $270 / 270$ & $30 / 16$ & $77 / 79$ & $28,7(15)$ & 11 & $26730 / 26730$ & $2841,3 / 1350$ \\
\hline Всього за добу 24 & - & - & - & - & - & $87060 / 89625$ & $10285,5 / 5512$ \\
\hline
\end{tabular}

Після зупинки на 2 год роботи насосів свердловин, водогін у межах водозабірних свердловин спорожниться, перейде в безнапірний режим, внаслідок чого режим роботи свердловинних насосів буде в області нижчих напорів та більшої подачі води. Результати розрахунків енергетичних витрат (див. табл. 2, 3) дають переконливу перевагу роботи свердловин водозабору з перервою для такого водогону.

Режсм рівномірної роботи водогону та НПС. Внаслідок рівномірної роботи $Q_{m i d}=87000 / 24=$ $3625 \mathrm{~m}^{3} /$ год за період $t_{o c}$ зупинки $n$ насосів буде спорожнено об'єм водогону

$$
W_{c}=Q_{\text {mid }} t_{o c} .
$$

Це становить довжину водогону

$$
L=\frac{W_{c}}{\omega} .
$$

Для нашого прикладу буде становити $W_{c}=7250 \mathrm{M}^{3}$ за $t_{o c}=2$ год. 3 цієї довжини водогону 4600 м знаходяться в межах свердловин водозабору, сюди вода надійде відразу після ввімкнення насосів, без додаткового істотного часу на протікання води по водогону. Щоб не сталося розірвання потоку води за довжиною водогону, iї добовий об'єм $W_{\text {mid }}$ повинен долати відстань до ПНС за час 24 год $-t_{o c}$ зі швидкістю, визначеною за формулою

$$
V_{l}=\frac{W_{m i t}}{\left(24-t_{o c}\right) \omega 3600} \mathrm{M} / \mathrm{c} .
$$

Для заданих експлуатаційних умов становить $V_{1}=$ 1,16 м/с. Поповнення спорожненого об'єму водогону можна здійснювати таким способом:

- ввімкненням в роботу однієї додаткової свердловини на час близько 10 год;

- збільшенням подачі води насосами свердловин (але не вище іï дебіту) внаслідок зменшення їх напору після спорожнення частини водогону.

Режсим нерівномірної роботи водогону та НПС. За нерівномірної роботи ПНС, а саме внаслідок збільшення подачі води ПНС, важливо, щоб не сталось розриву потоку через спорожнення водогону під час перерви роботи свердловин. Як час, так і довжина спорожненої ділянки перед ПНС може бути обмежена технологічними умовами. Тому для заданих об'ємів подачі ПНС $Q_{N S}$ та часу $T_{N S}$ iї роботи, за яким забезпечиться суцільність потоку води, можна визначити відстані $l_{1}, l_{0}$ переміщення об'ємів води у водогоні (рис. 5).

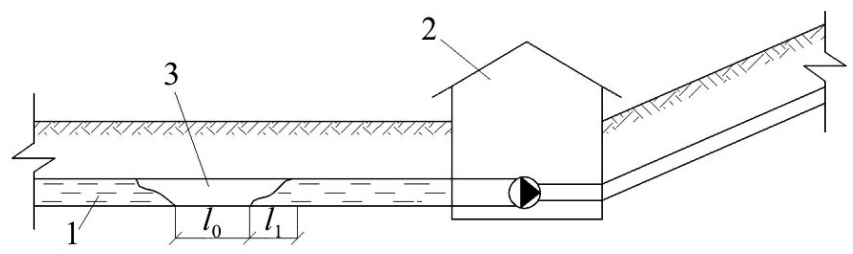

Рис. 5. Схема до розрахунку: 1) водогін; 2) НПС; $1_{0}$-довжина спорожненої ділянки водогону; $1_{1}$ - довжина переміщення об'єму води у водогоні за заданий час роботи ПНС

Довжину переміщення $l_{1}$ визначаємо за формулою

$$
l_{1}=\frac{W}{\omega}=\frac{Q_{N C} T_{N C}}{\omega} .
$$

Швидкість води у водогоні на ділянці перед ПНС $V_{1}$ $=Q_{N S} / \omega$. Залежно від подачі води свердловинами верхня ділянка водогону буде характеризуватись швидкостями $V_{2}$ та часом $T_{i n}$ долання потоком ділянки $l_{1}+l_{0} T_{N s}$. Мінімальну швидкість $V_{2}$ води на ділянці від свердловин визначаємо $з$ умов рівності часу добігання $T_{N S}=T_{i n}$ або

$$
\frac{l_{0}+l_{1}}{V_{2}}=\frac{l_{1}}{V_{1}} .
$$

Тоді визначаємо необхідну загальну подачу води для цього періоду експлуатації.

\section{Висновки}

1. Встановлено, що гідравлічний режим у водогоні зі значним ухилом на ділянці від свердловин водозабору до підвищувальної насосної станції є напірним або ж безнапірним залежно від величини подачі води.

2. З'ясовано, що розрахункова гідравлічна швидкість води у водогоні від водозабору до ПНС повинна бути не нижчою, ніж необхідна мінімальна швидкість протікання розрахункового об'єму води за визначений термін. Швидкість протікання добового об'єму води по водогону від свердловин водозабору до підвищувальної насосної станції є додатковим показником для розрахунків довгих водогонів. Це доповнює теоретичні основи методології розрахунків довгих водогонів.

3. Враховуючи те, що водогін до ПНС має значний регулювальний об'єм води, водозабірні свердловини водозабору "Стрий" економічно вигідно експлуатувати 3 частковою перервою протягом доби. Свердловинні насоси ЕЦВ 12-255-30 водозабору "Стрий" мають напір 27-35 м, який є вищим від необхідного, та потужність 23-27 кВт. Тому доцільно їх замінити на насоси SP 270- 
L1-G з регульованими характеристиками, що дає економію електроенергії ( $\approx 4,5$ тис. кВт/год у добу).

4. Результати цього дослідження можна застосувати під час модернізації обладнання свердловин і насосних підвищувальних станцій на водогонах. Дослідження виконали для постійного ухилу водогону зі зниженням до ПНС. Їхні результати не можна застосувати у разі змінного ухилу або підвищення траси водогону до ПНС.

\section{References}

Anis, M. D. (2018). Identifying a Mathematical Model to Optimize Pump Maintenance Planning Decisions - A Case of Irrigation Asset Management in K.S.A

Chernyuk, V., \& Orel, V. (2009). Experimental Verification of a New Method of Calculation for Pressure Distributive Pipelines. Zeszyty Naukowy Politechniki Rzeszowskiej. Budownictwo i Inżynieria Środowiska, Rzeszów, Poland, Politechnika Rzeszowska, 266(54), 27-34.

Chupin, R. V., \& Pham, M. N. (2019). Optimal reconstruction of water supply network under conditions of reduced water consumption.

Fang, H., Wu, W., Lv, M., \& Gao, J. (2011). Optimising pump system with constant and variable speed pumps: case study. International Journal of Modelling, Identification and Control, 12(4), 412-420.

Filipek, K., \& Kulig, M. (2018). Przygotowanie systemu zaopatrzenia w wodę do działań w warunkach kryzysowych w świetle obowiązujących norm i przepisów prawnych. Gaz, Woda i Technika Sanitarna, 9, 364-368.

Grundfos. (2019). Kataloh GRUNDFOS. Retrieved from: https://mnk-rus.com/d/1176894/d/katalog_spg skvazhinnyye nasosy.pdf. [In Ukrainian].

Hurynovich, A., \& Sycziowa, E., (2016) Metodyka projektowania ujęć wód podziemnych z uwzględnieniem cyklu życia studni głębinowych i agregatów pompowych. Gaz, Woda i Technika Sanitarna, 4, 364-368

Kadar, Y., \& Bariudin, V. (2001). Optimization model for the design of water supply network. Bridging the Gap: Meeting the Worlds Water and Environmental Resources Challenges: Proceedings of the World Water and Environmental Resources Congress 2001.

Konstantinov, Yu. M., \& Hizha, O. O. (2006). Inzhenerna hidravlika. Kyiv: Publishing House "Slovo", 432 p. [In Ukrainian].

Konstantinov, Yu. M., \& Hizha, O. O. (2015). Rozrakhunky napirnykh truboprovodiv za shvydkisnymy ta vytratnymy kharak- terystyka. Zbirnyk naukovykh prats KNUBA 25, 104-112. [In Ukrainian].

Livnynasos. (2019). Kataloh nasosiv AO "Livnynasos". Retrieved from: https://www.livnasos.ru/catalog/nasosy_ecv/ecv_12/ecv_12255-30_nro/. [In Ukrainian].

Lukyn, N. A., Usachev, A. P., \& Hordeichyk, A. V. (2018). Cystema upravlenyia skvazhynnym vodozaborom "Cmychka" h. Semei. Vodoochystka. Vodopodhotovka. Vodosnabzhenie, 5, 46-51. [In Russian].

Nor, V. V. (2017). Doslidzhennia problemy zabezpechennia efektyvnoi roboty system podachi i rozpodilu vody ta shliakhiv yii vyrishennia. Zbirnyk naukovykh prats KNUBA, 28, 249-257. [In Ukrainian].

Prodous, O. A., \& Terekhov, L. D. (2018). Analyz rezhymov raboty samotechno-napornoho vodovoda s bolshym perepadom vysot. Vodoochystka. Vodopodhotovka. Vodosnabzhenye, 10, 26-30. [In Russian].

Rak, J., \& Boryczko, K. (2017). Metod otsinky dyversyfikatsii efektyvnosti vodozaboru ta obiemu merezhi rezervuariv dlia vodopostachannia. Gaz, Woda i Technika Sanitarna, 11, 157-158.

Shevelev, F. A, \& Shevelev, A. A. (2007). Tablytsy dlia hydravlycheskoho rascheta vodoprovodnykh trub. Spravochnoe posobye. Moscow: OOO "Bastet", 350 p. [In Russian].

Sousa, C. M., Covas, D. I. C., \& Ramos, H. M. (2007). Multiobjective optimization of water supply system operation using Genetic Algorithms. Proceedings of the Combined International Conference of Computing and Control for the Water Industry, and Sustainable Urban Water Management, (pp. 425-432).

Studziński, J. (2015). ICS system supporting the water networks management by means of mathematical odeling and optimization algorithms. Journal of Automation, Mobile Robotics and Intelligent Systems, 9(4), 48-54.

Studziński, J., \& Kurowski, M. (2014). Some algorithms supporting the water network management by use of simulation of network hydraulic model. 12th International Industrial Simulation Conference, (pp. 33-37).

Vieira, F., \& Ramos, H. M. (2009). Optimization of the energy management in water supply systems. Water Science and Technology: Water Supply, 9(1), 59-65.

Wiśniewska, K., Kowalska, B., Kowalski, D., Kuzioła, E., \& Hołota, E. (2017). Ocena niezawodności wybranej stacji wodociągowej w oparciu o wskaźnik gotowości. Gaz, Woda i Technika Sanitarna, $11,476-471$.

M. P. Bosak', M. S. Odukha', O. H. Hvozdetskiy', V. Ye. Fasuliak ${ }^{1}$

${ }^{1}$ Lviv Polytechnic National University, Lviv, Ukraine

${ }^{2}$ Lviv City Communal Enterprise "Lvivvodokanal", Lviv, Ukraine

\section{RESEARCH OF THE OPERATION MODE OF PERFORMANCE OF WATER SUPPLY AND WATER INTAKE WELLS}

An analytical study of the modes of operation of Stryi water intake wells and the water supply to the city of Lviv was performed on the site to the pumping station. Groundwater abstraction was made from 34 wells. Actual water supply in recent years averages $87,000 \mathrm{~m}^{3} /$ day, projected water intake performance is found to be significantly higher. A characteristic feature of this water supply system is its geodetic reduction by $50 \mathrm{~m}$ at a distance from the water intake to the upstream pumping station. The studies were performed for the constant inclination of the water supply to the upstream pumping station. The main task of the work is to determine and justify the economical mode of operation of the water supply system on the basis of hydraulic studies. The method of research is theoretical analysis based on well performance. The presence of pressureless and pressure flow of water in the water supply system is determined depending on the size of water supply. The unpressurized flow is found to be characteristic of water flow in the range $3000-4000 \mathrm{~m}^{3} / \mathrm{h}$. At high costs in the water system there is a pressure flow regime. It is also found that the amount of water supply is not exactly the same with the pumping wells and the upstream pumping station, therefore water pressure in the water supply is variable. The operating pressure of the well pumps, which is $30 \mathrm{~m}$, is estimated to be excessive for these conditions. Two modes of operation of wells of water supply and intake are analyzed. The economical variant of operation of well pumps is determined. The study has confirmed that it is advisable to replace well pumps with those with a lower head and higher efficiency. The feasibility of operating wells in the mode with a break of work of well pumps for a time of about 2 hours per day is substantiated. Therefore, the well within the water intake wells will be emptied and the mode of operation of the downhole pumps will be in the area of low head and larger water supply. As a result, the energy consumption of the pumps will be reduced. Additional knowledge about the features of water intake and water supply was obtained. The results of this study can be applied to the modernization of wells and pumping stations.

Keywords: wells; a water supply with a pumping station; operation mode; pressure and gravitational modes. 